\title{
Fertilization of Tifton 85 with Swine Liquid Manure
}

\author{
Marinho Rocho da Silva', Joadil Gonçalves de Abreu1, Oscarlina Lúcia dos Santos Weber¹, \\ Flabiele Soares da Silva1, Edna Maria Bonfim-Silva2 ${ }^{2}$, Ana Paula Alves Barreto Damasceno ${ }^{2}$ \\ ${ }^{1}$ Faculty of Agronomy and Animal Science, Federal University of Mato Grosso, Cuiabá, Brasil \\ ${ }^{2}$ Department of Agricultural and Environmental Engineering, Institute of Agricultural Sciences and Technology, Federal University \\ of Mato Grosso, Rondonópolis, Brazil \\ Email: *embonfim@hotmail.com
}

How to cite this paper: da Silva, M.R., de Abreu, J.G., dos Santos Weber, O.L., da Silva, F.S., Bonfim-Silva, E.M. and Damasceno, A.P.A.B. (2019) Fertilization of Tifton 85 with Swine Liquid Manure. Agricultural Sciences, 10, 918-926.

https://doi.org/10.4236/as.2019.107070

Received: June 19, 2019

Accepted: July 16, 2019

Published: July 19, 2019

Copyright (c) 2019 by author(s) and Scientific Research Publishing Inc. This work is licensed under the Creative Commons Attribution International License (CC BY 4.0).

http://creativecommons.org/licenses/by/4.0/

\begin{abstract}
The objective was to verify the possibility of supplying the nutritional requirement of Tifton 85 grass with swine liquid manure in an intensive management system. The experiment was carried out in a randomized block design, with four treatments of swine liquid manure doses: 0, 70, 140 and 210 $\mathrm{m}^{3} \cdot \mathrm{ha}^{-1}$, divided into seven applications and a treatment of mineral fertilization of $200 \mathrm{~kg}$ of nitrogen $\mathrm{ha}^{-1} \cdot \mathrm{year}^{-1}$. Samples of the collected plant material were weighed to obtain fresh mass taken for drying and then ground for bromatological determination. The dry mass production data were obtained by dry matter accumulation during the cuts and averages were made for the variables; plant height, crude protein, $\mathrm{NDF}, \mathrm{ADF}$, neutral detergent insoluble protein (NDIP) and acid detergent insoluble protein (ADIP). The data were subjected to variance analysis, performing regression for swine liquid manure doses and averages test (Dunnett test) to compare the doses with the mineral fertilization. Higher plant heights, dry mass production, crude protein content, neutral detergent insoluble protein content and lower neutral detergent fiber content in Tifton 85 grass were observed with mineral fertilization. In the variables, acid detergent fiber and acid detergent insoluble protein there was no difference $(P=0.05)$ between the mineral fertilization and the swine liquid manure doses. There was a linear increase $(P=0.05)$ of swine liquid manure doses only in dry matter production. Swine liquid manure doses up to $210 \mathrm{~m}^{3} \cdot \mathrm{ha}^{-1} \cdot \mathrm{year}^{-1}$ do not meet the entire nutritional requirement of Tifton 85 grass, recommending the evaluation of higher swine liquid manure doses or complementation with mineral fertilization.
\end{abstract}

\section{Keywords}

Bromatology, Cynodon spp., Organic Fertilization, Waste Reuse 


\section{Introduction}

Swine farming is considered a potentially polluting activity due to the waste production generated, which consist of animals feces, leftover ration, urine, excess water from drinkers and water used in the hygiene of the stalls [1].

Therefore there is great concern in making the rational disposal of these residues in the environment, so that there is no compromise of soil, plants and water resources [2]. One of the causes of pasture degradation is the fertilization absence, the use of swine liquid manure as a source of nutrients is an alternative to be used [3] [4].

The swine liquid manure contains in its composition, organic matter, nitrogen, phosphorus, potassium, calcium, sodium, magnesium, manganese, iron, zinc and copper [5] [6]. Typically, it contains from $70 \%$ to $80 \%$ of total $\mathrm{N}$ as ammonium, which is an available form of $\mathrm{N}$ for plants [7].

The application of swine liquid manure increases the supply of $\mathrm{N}$ [8] and $\mathrm{P}$ [6] to soil, in order to promote plant growth and enhance the leaf/stem ratio [1].

Therefore, fertilization with swine liquid manure may be a viable option [9] [10] [11] [12] in case the soil adsorption capacity and the need for crops are respected [13] mainly among tropical grasses cultivated with high yield, such as Cynodon spp. cv. Tifton 85.

It is verified that there is variability in the recommendation, in studies by [14] [15], on the effect of fertilization of Tifton 85 grass, whose values ranged from 200 to $500 \mathrm{~m}^{3} \cdot \mathrm{ha}^{-1} \cdot \mathrm{year}^{-1}$ of swine liquid manure, respectively.

Faced with this variability, the objective of this study was to evaluate whether or not the swine liquid manure replaces the mineral fertilization of Tifton 85 grass in an intensive system.

\section{Material and Methods}

\subsection{Description of the Study Area}

The experiment was carried out at the Experimental station of the Rio Verde Foundation $\left(13^{\circ} 00^{\prime} 02^{\prime \prime S}\right.$ and $\left.55^{\circ} 58^{\prime} 15^{\prime \prime} \mathrm{O}\right)$, located in Lucas do Rio Verde municipality, Mato Grosso state. The soil of the region is classified as Oxisol, according to the classification of [16].

The region climate, according to the Köppen classification, is of the type Aw, tropical rainy, hot and humid, with a prolonged dry season and wet season of seven months, between October and April (Figure 1).

The swine liquid manure used came from the swine sector of the Federal Institute of Mato Grosso, Campus São Vicente-MT, coming from a stabilization pond.

\subsection{Treatments and Experimental Design}

The experimental design was randomized blocks with five treatments. The treatments consisted of four doses of swine liquid manure $\left(0,70,140\right.$ and $210 \mathrm{~m}^{3} \cdot \mathrm{ha}^{-1}$ 
per cut) and a mineral fertilization to meet $100 \%$ of the culture requirement, adopting the doses of 200,70 and $400 \mathrm{~kg} \cdot \mathrm{ha}^{-1}$ of nitrogen, phosphorus and potassium, respectively, in two production cycles. Four blocks were delineated in plowed and meshed area, with five plots of $55 \mathrm{~m}^{2}(11.0 \times 5.0 \mathrm{~m})$ in each block, separated by plots and between blocks of $1 \mathrm{~m}$.

The first cycle corresponded to months March, April and May of 2014; The second cycle: October 2014 to January 2015. The swine liquid manure doses applied were seven cuts of $0,10,20,30 \mathrm{~m}^{3} \cdot \mathrm{ha}^{-1} \cdot \mathrm{year}^{-1}$. The experimental area was occupied in the previous crop with soybean crop, which left residue for the subsequent crop.

The swine liquid manure was manually applied with 10 litre capacity-watering rooms, in the volumes recommended for each treatment shortly after the cuts. To avoid possible contamination of the plots, by surface runoff, was placed on the sides of each portion PVC plates forming a protection barrier due to a soil slope.

Soil samples were collected in two depths ( 0 to 10 and 10 to $20 \mathrm{~cm}$ ) for the determination of the chemical analysis (Table 1) according to methodologies recommended by authors [17].

The swine liquid manure was stored in open ponds, being under the incidence and variation of the rains (Figure 1), which may have caused some dilution, this way, a sample was collected monthly to analyze its chemical composition. The sample was refrigerated and stored for macronutrient analysis. The average

Table 1. Soil fertility chemical analysis of the experimental area at different depths from 0 to 10 and 10 to $20 \mathrm{~cm}$.

\begin{tabular}{cccccccccccc}
\hline Depth & $\mathrm{pH}$ & $\mathrm{Al}$ & $\mathrm{H}+\mathrm{Al}$ & $\mathrm{Ca}$ & $\mathrm{Mg}$ & $\mathrm{T}_{\mathrm{pH} 7,0}$ & $\mathrm{~V}$ & $\mathrm{M}$ & $\mathrm{OM}$ & $\mathrm{K}$ & $\mathrm{P}$ \\
\hline$(\mathrm{cm})$ & $\left(\mathrm{CaCl}_{2}\right)$ & \multicolumn{3}{c}{$\left(\mathrm{cmol}_{\mathrm{c}} \cdot \mathrm{dm}^{-3}\right)$} & & & $(\%)$ & & \multicolumn{3}{c}{$\left(\mathrm{mg} \cdot \mathrm{dm}^{-3}\right)$} \\
\hline $0-10$ & 4.91 & 0.24 & 17.60 & 2.32 & 2.24 & 22.17 & 20.61 & 4.98 & 5.56 & 4.07 & 21.8 \\
$10-20$ & 4.70 & 0.40 & 14.10 & 1.30 & 1.30 & 16.71 & 15.61 & 13.28 & 5.27 & 2.79 & 3.70 \\
\hline
\end{tabular}

pH-acidity; OM-organic matter; $\mathrm{P}$-phosphorus; $\mathrm{K}$-potassium; Ca-calcium; $\mathrm{Mg}$-magnesium; $\mathrm{H}+$ $\mathrm{Al}-$ Hydrogen plus aluminum; $\mathrm{T}-$ cationic exchange capacity; $\mathrm{V}-$ base saturation.

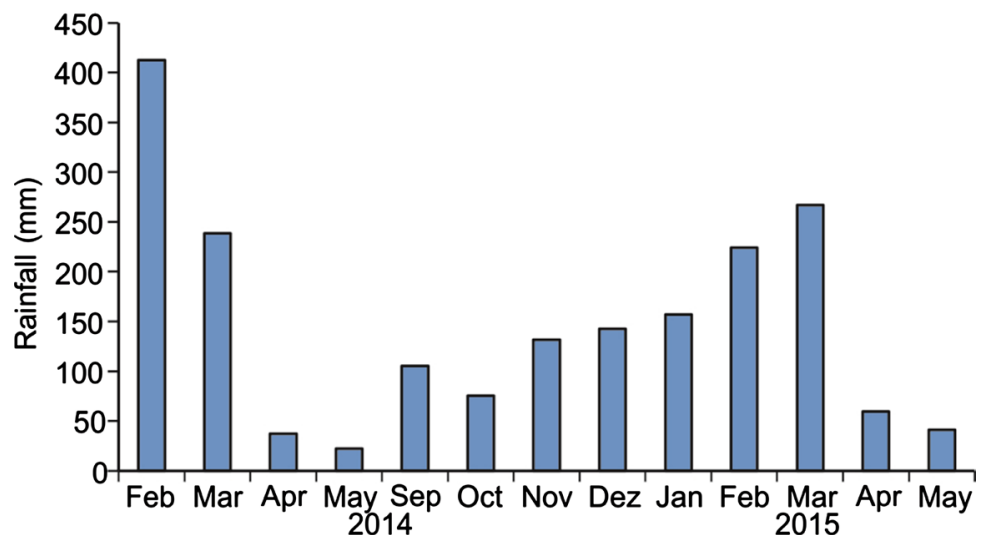

Figure 1. Rainfall in the experimental period at Fundação Rio Verde (Lucas do Rio Verde). 
chemical composition of the swine liquid manure consisted of: Total N: 3500 $\mathrm{mg} \cdot \mathrm{L}^{-1}$; P: $1617.66 \mathrm{mg} \cdot \mathrm{L}^{-1}$; K: $461.34 \mathrm{mg} \cdot \mathrm{L}^{-1}$; Ca: $2994.8 \mathrm{mg} \cdot \mathrm{L}^{-1}$; Mg: $1084 \mathrm{mg} \cdot \mathrm{L}^{-1}$; $\mathrm{S}: 1179 \mathrm{mg} \cdot \mathrm{L}^{-1}$. With the nitrogen content, the volume of swine liquid manure to be applied in each cut was calculated.

The planting of Tifton 85 grass seedlings was carried out in January 2014, after 30 days, a uniformity cut at $15 \mathrm{~cm}$ of residue height was performed. In March 2014, the first measurements of the plant height were performed at 10 sites per plot, and three forage samples were collected from each plot at the residue height $(15 \mathrm{~cm})$ using a square of $0.5 \times 0.5 \mathrm{~m}$.

\subsection{Soil Sampling, Preparation and Analysis}

Samples of the collected plant material were weighed to obtain fresh mass and packaged in paper bags, duly identified and taken for drying in air circulation incubator, at temperature of $60^{\circ} \mathrm{C}$ to constant weight. The dry material was then grinded into a Willey mill and properly stored with identification for further determination of the bromatological composition.

The $\mathrm{N}$ content was determined by the Kjeldahl method as the authors [18]. For the determination of the fibrous fraction, the methods described by the author [19], which divides the sample components into neutral detergent insoluble fiber (NDF) and acid detergent insoluble fiber (ADF).

The dry mass production data were obtained by dry matter accumulation during the cuts and averages were made for the variables; plant height, crude protein, NDF, ADF, neutral detergent insoluble protein (NDIP) and acid detergent insoluble protein (ADIP).

\subsection{Statistical Analysis}

The data were subjected to variance analysis, performing regression for swine liquid manure doses and averages test (Dunnett test) to compare the doses with the mineral fertilization.

\section{Results and Discussion}

When comparing the mineral fertilization with swine liquid manure doses by Dunnett means test $(P=0.05)$, higher plant height, dry mass production, crude protein content, NDIP content and lower NDF content in Tifton 85 grass were observed in mineral fertilization (Figure 2). For the ADF and ADIP variables there was no significant difference between the swine liquid manure doses and mineral fertilization (Table 2).

The mineral fertilization complied with the requirements of Tifton 85 grass, providing higher plant height $(55.27 \mathrm{~cm})$ and higher dry mass production $(30.52$ $\mathrm{kg} \cdot \mathrm{ha}^{-1}$ ) (Figure 2). The levels of NPK, in the swine liquid manure volume, were not sufficient to meet the nutrient requirement, because Tifton 85 grass is highly demanding in relation to fertility and inadequate supply can cause the reduction of forage production, nutritive value and nutrient concentrations [20]. 

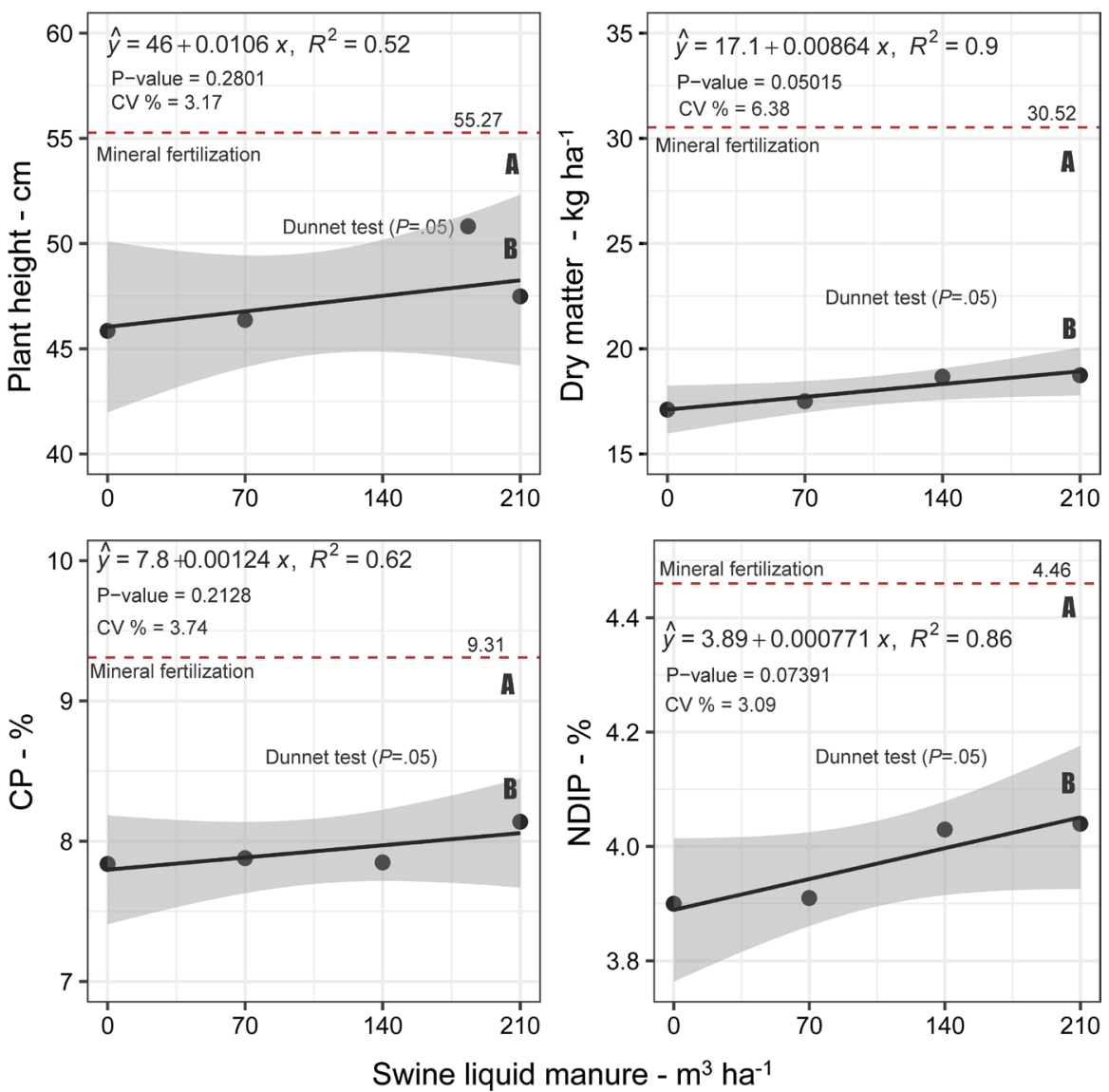

Figure 2. Production and bromatological composition of Tifton 85 grass fertilizing with different swine liquid manure doses and mineral fertilization in two production cycles. Red dashed line-mineral fertilization with 200,70 and $400 \mathrm{~kg} \cdot \mathrm{ha}^{-1}$ of nitrogen, phosphorus and potassium, respectively. Means followed by the same letter do not differ from each other by the Dunnet test $(\mathrm{P}<0.05)$. CP $(\%)$-Crude protein; NDIP $(\%)$ - Neutral detergent insoluble protein.

The lowest crude protein content in the swine liquid manure doses compared to mineral fertilization (Figure 2) may be related to variations in the nutrient concentration of the slurry, since the doses were fixed in volumes. However, in the highest swine liquid manure dose the crude protein content was above $8 \%$, considered the minimum percentage sufficient for an adequate microbial ruminants activity [21].

Only in the mineral fertilization, the NDF contents (Table 2) were close to those that the author [19] established, that is, that lower or equal levels of $65 \%$, do not impair the forage intake by the animals and guarantee the ruminal microorganisms greater utilization of the dietary nutrients consumed by the animal, providing better performance. The highest NDF levels (67.17\% to 67.90\%) is a particularity presented in Tifton Grass 85 [22] [23].

However the authors [24] cite that even this forage with values greater than $65 \%$ is possible to have good digestibility, because the cellular compounds have fewer ester-type bonds involving ferulic acid, a compound phenolic digestibility 
Table 2. Production and bromatological composition of Tifton 85 grass fertilizing with swine liquid manure doses and mineral fertilization in two production cycles.

\begin{tabular}{ccccccc}
\hline \multirow{2}{*}{ Variables } & \multicolumn{5}{c}{ Swine liquid manure doses $\left(\mathrm{m}^{3} \cdot \mathrm{ha}^{-1}\right)$} & \\
\cline { 2 - 6 } & 0 & 70 & 140 & 210 & Mineral fertilizer & CV (\%) \\
\hline NDF (\%) & $67.41^{\mathrm{b}}$ & $67.17^{\mathrm{b}}$ & $67.90^{\mathrm{b}}$ & $67.76^{\mathrm{b}}$ & $65.76^{\mathrm{a}}$ & 0.86 \\
$\mathrm{ADF}(\%)$ & $33.93^{\mathrm{a}}$ & $33.71^{\mathrm{a}}$ & $33.86^{\mathrm{a}}$ & $34.01^{\mathrm{a}}$ & $33.86^{\mathrm{a}}$ & 1.05 \\
$\mathrm{ADIP}(\%)$ & $0.78^{\mathrm{a}}$ & $0.75^{\mathrm{a}}$ & $0.83^{\mathrm{a}}$ & $0.75^{\mathrm{a}}$ & $0.78^{\mathrm{a}}$ & 8.06 \\
\hline
\end{tabular}

NDF (\%)—Neutral detergent insoluble fiber; ADF (\%) - Acid detergent insoluble fiber; ADIP (\%)-Acid detergent insoluble protein; ${ }^{*}$ Mineral fertilizer-200, 70 and $400 \mathrm{~kg} \cdot \mathrm{ha}^{-1}$ of nitrogen, phosphorus and potassium, respectively. Medium followed by the same letter in line do not differ by Dunnett test.

inhibitor. The highest levels of NDF are related to higher plant height observed.

There was no significant difference between the levels of acid detergent fiber (ADF) between the swine liquid manure doses and mineral fertilization (Table 2). The ADF contents are within the ideal range, as fodder with levels around $30 \%$ of ADF or less are more digestible [18].

The contents of PIDN were close to those observed by the authors [25] at 28 days of interval between the cuttings for the production of Tifton 85 grass (Figure 2). While the ADIP levels were lower than those observed by the same author (Table 2). The results show the need for studies with higher doses of swine liquid manure for Tifton 85 grass, considering the values obtained are below the values observed in the mineral fertilization.

For the swine liquid manure doses, there was a significant effect on the dry matter production variable (Figure 2). There was an increasing linear effect $(\mathrm{P}>$ 0.05) of the mineral fertilizer dose on dry matter production (Figure 2). Similar results were verified by authors [26] [27] in the dry mass production of pasture, in which they verified the linear growth according to the swine liquid manure doses.

According to authors [7] swine waste doses $\left(500 \mathrm{~kg} \cdot \mathrm{ha}^{-1} \cdot \mathrm{year}^{-1}\right)$ that did not reach the plateau of dry matter production, it allows, according to the authors, quadruplicate the daily dose of forage production, without the reduction in agronomic efficiency.

The estimated dry matter production was $18.928 .25 \mathrm{~kg} \cdot \mathrm{ha}^{-1} \cdot \mathrm{year}^{-1}$, obtained with the application of $210 \mathrm{~m}^{3} \cdot \mathrm{ha}^{-1} \cdot \mathrm{year}^{-1}$ of swine liquid manure, with an increment of $9.60 \%$, when compared to the treatment without swine liquid manure.

Close results were obtained by authors [27] who worked with four swine liquid manure treated doses and, with and without irrigation, obtaining an estimated yield of $19.535 .5 \mathrm{~kg} \mathrm{DM} \mathrm{ha}{ }^{-1} \cdot \mathrm{year}^{-1}$ at the dose of $210 \mathrm{~m}^{3} \cdot \mathrm{ha}^{-1}$ of swine liquid manure, when in the presence of irrigation. However, this value may vary according to the stocking rate used, justing the magnitude of response to nitrogen fertilization in the different cuts [8].

\section{Conclusions}

The application of swine liquid manure has its use justified by the increase in dry 
mass production of Tifton 85 grass. There was a significant increase with the use of the manure in relation to its non-use.

Swine liquid manure doses up to $210 \mathrm{~m}^{3} \cdot \mathrm{ha}^{-1}$ do not supply the entire nutritional requirement of Tifton 85 grass, recommending the evaluation of higher swine liquid manure doses.

Due to the increasing linear effect in the dry matter production, the maximum dose used in the present experiment may be increased, but there is a need for studies on environmental impacts.

\section{Conflicts of Interest}

The authors declare no conflicts of interest regarding the publication of this paper.

\section{References}

[1] Serafim, R.S. and Galbiatti, J.A. (2012) Efeito da aplicaçao de água residuária de suinocultura na Brachiaria Brizantha cv Marandu. Revista Colombiana de Ciencia Animal, 4, 185-203. https://doi.org/10.24188/recia.v4.n1.2012.307

[2] Yuan, Z., Pan, X., Chen, T., et al. (2018) Evaluating Environmental Impacts of Pig Slurry Treatment Technologies with a Life-Cycle Perspective. Journal of Cleaner Production, 188, 840-850. https://doi.org/10.1016/j.jclepro.2018.04.021

[3] Costa, K.A., Faquin, V. and Oliveira, I. (2010) Doses e fontes de N recuperação de pastagem marandu. Arquivo Brasileiro de Medicina Veterinaria e Zootecnia, 62, 192-199. https://doi.org/10.1590/S0102-09352010000100026

[4] Pandolfo, C.M. and Veiga, M.da. (2016) Crop Yield and Nutrient Balance Influenced by Shoot Biomass Management and Pig Slurry Application. Revista Brasileira de Engenharia Agrícola e Ambiental, 20, 302-307. https://doi.org/10.1590/1807-1929/agriambi.v20n4p302-307

[5] Serpa Filho, R., Sehnem, S., Cericato, A., Santos Junior, S. and Fischer, A. (2013) Compostagem de dejetos de suínos. Revista em Agronegócios e Meio Ambiente, 6, 47-78.

[6] Boitt, G., Schmitt, D.E., Gatiboni, L.C., et al. (2018) Fate of Phosphorus Applied to Soil in Pig Slurry under Cropping in Southern Brazil. Geoderma, 321, 164-172. https://doi.org/10.1016/j.geoderma.2018.02.010

[7] Brustolin-Golin, K.D., Scheffer-Basso, S.M., Escosteguy, P.A.V., Miranda, M., Travi, M.R.L. and Zabot, V. (2016) Pig Slurry in Carpet Grass Pasture: Yield and PlantAvailable Nitrogen. Revista Brasileira de Engenharia Agrícola e Ambiental, 20, 795-799. https://doi.org/10.1590/1807-1929/agriambi.v20n9p795-799

[8] Galindo, F.S., Buzetti, S., Teixeira Filho, M.C.M., Dupas, E. and Carvalho, F.C. (2018) Nitrogen Management in Mombasa Guineagrass as a Function of Sources and Rates of Nitrogen. Revista de Ciências Agrárias, 41, 31-40.

[9] Seidel, E.P., Gonçalves Júnior, A.C., Vanin, J.P., Strey, L., Schwantes, D. and Nacke, H. (2010) Aplicação de dejetos de suínos na cultura do milho cultivado em sistema de plantio direto. Acta Scientiarum. Technology, 32, 113-117. https://doi.org/10.4025/actascitechnol.v32i2.5312

[10] Lee, C.-T., Rahman, Z.A, Musa, M.H., Norizan, M.S. and Tan, C.-C. (2011) Leaf Nutrient Concentrations in Oil Palm as Affected by Genotypes, Irrigation and Ter- 
rain. Journal of Oil Palm and the Environment, 2, 38-47.

[11] Egewarth, V.A., Egewarth, J.F., Prior, M., et al. (2015) The Effect of Swine Raising Wastewater in the Development of Millet (Pennisetum glaucum L.), Soil and Leachate. African Journal of Agricultural Research, 10, 3206-3215. https://doi.org/10.5897/AJAR2015.9872

[12] Gomes, E.P., Sanches, A.C., Deboleto, J.G.G., de Jesus, F.L.F. and Mendonça, F.C. (2017) Productivity and Nutritional Quality of Urochloa brizantha cv. BRS Piatã Grass Fertirrigated with Swine Wastewater in Different Seasons of the Year. Australian Journal of Crop Science, 11, 1366-1373. https://doi.org/10.21475/ajcs.17.11.10.pne732

[13] Ceretta, C.A., Girotto, E., Lourenzi, C.R., Trentin, G., Vieira, R.C.B. and Brunetto, G. (2010) Nutrient Transfer by Runoff under No Tillage in a Soil Treated with Successive Applications of Pig Slurry. Agriculture, Ecosystems and Environment, 139, 689-699. https://doi.org/10.1016/j.agee.2010.10.016

[14] Drumond, L.C.D., Zanini, J.R., Aguiar, A.P.A., Rodrigues, G.P. and Fernandes, A.L.T. (2006) Produção de matéria seca em pastagem de tifton 85 irrigada, com diferentes doses de dejeto líquido de suíno. Engenharia Agricola, 26, 426-433. https://doi.org/10.1590/S0100-69162006000200010

[15] Rezende, V.O., Drumond, L.C.D., Lana, R.M.Q., Carvalho, A.M.X. and Silva, A.A. (2014) Efeito da fertirrigação com água residuária de suinocultura na produção dos capins tifton 85. XLII Congresso Brasileiro de Engenharia Agrícola, Campo Grande, $1-8$.

[16] Santos, H.G., Jacomine, P.K.T., Anjos, L.H.C., et al. (2018) Sistema Brasileiro de Classificação de Solos, Embrapa So. Rio de Janeiro.

[17] Parron, L.M., Muniz, D.H.F. and Pereira, C.M. (2011) Manual de Procedimentos de Amostragem e Análise Físico-Química de Água. Embrapa Florestas Documentos 2322011.

[18] Silva, D. and Queiroz, A.C. (2006) Análise Dos Alimentos (Métodos Químicos e Biológicos). 3rd Edition, Viçosa.

[19] Van Soest, P. (1994) Nutritional Ecology of the Ruminant. Ithaca and London.

[20] Castagnara, D.D., Krutzmann, A., Zoz, T., et al. (2012) Effect of Boron and Zinc Fertilization on White Oats Grown in Soil with Average Content of These $\mathrm{Nu}$ trients. Revista Brasileira de Zootecnia, 41, 1598-1607. https://doi.org/10.1590/S1516-35982012000700007

[21] Lazzarini, I., Detmann, E., Sampaio, C.B., et al. (2009) Dinâmica ruminal da fibra em detergente neutro em bovinos alimentados com forragem tropical de baixa qualidade e suplemento com compostos nitrogenados. Revista Brasileira de Zootecnia, 61, 635-647. https://doi.org/10.1590/S0102-09352009000300017

[22] Hill, G.M., Newton, G.L., Streeter, M.N., Hanna, W.W., Utley, P.R. and Mathis, M.J. (1996) Digestibility and Utilization of Pearl Millet Diets Fed to Finishing Beef Cattle. Journal of Animal Science, 74, 1728-1735.

https://doi.org/10.2527/1996.7471728x

[23] Andrade, A.S., Drumond, L.C.D., Rabelo, D.M.L., Appelt, M.F., Lima, J.C.L. and Oliveira, V.M.R. (2014) Crescimento de gramíneas forrageiras fertirrigadas com água residuária de suinocultura. Revista Trópica: Ciências Agrárias e Biológicas, 8 , 59-71.

[24] Hatfield, R.D., Mandebvu, P. and West, J. (1997) A Comparison of Tifton 85 and Coastal Bermudagrass Cell Walls. US Dairy Forage Research Center, 1, 49-50. 
[25] Gonçalves, G.D., Dos Santos, G.T., Jobim, C.C., Damasceno, J.C., Cecato, U. and Branco, A.F. (2003) Determinação do consumo, da digestibilidade e das frações protéicas e de carboidratos do feno de tifton 85 em diferentes idades de corte. $R e$ vista Brasileira de Zootecnia, 32, 804-813.

https://doi.org/10.1590/S1516-35982003000400004

[26] Albuquerque, D.C.K., Scheffer-Basso, S.M., Escosteguy, P.A.V., Brustolin-Golin, K.D., Zabot, V. and Miranda, M. (2017) Residual Effect of Pig Slurry on Common Carpet Grass Pasture. Revista Brasileira de Engenharia Agrícola e Ambiental, 21, 374-378. https://doi.org/10.1590/1807-1929/agriambi.v21n6p374-378

[27] Cardoso, E.A.S., Gomes, E.P., Barboza, V.C., Dias, D.K.U., Deboleto, J.G. and Goes, R.H.T.B. (2015) Produtividade e qualidade do capim tifton 85 sob doses de dejeto líquido de suíno tratado na presença e ausência de irrigação. Cadernos de Agroecologia, 9, 1-10. 